\title{
Delivering effective social assistance: Does politics matter?
}

Link to publication record in Manchester Research Explorer

\section{Citation for published version (APA):}

Barrientos, A., \& Pellisery, S. (2012). Delivering effective social assistance: Does politics matter? (ESID Working Papers; No. 9).

\section{Citing this paper}

Please note that where the full-text provided on Manchester Research Explorer is the Author Accepted Manuscript or Proof version this may differ from the final Published version. If citing, it is advised that you check and use the publisher's definitive version.

\section{General rights}

Copyright and moral rights for the publications made accessible in the Research Explorer are retained by the authors and/or other copyright owners and it is a condition of accessing publications that users recognise and abide by the legal requirements associated with these rights.

\section{Takedown policy}

If you believe that this document breaches copyright please refer to the University of Manchester's Takedown Procedures [http://man.ac.uk/04Y6Bo] or contact uml.scholarlycommunications@manchester.ac.uk providing relevant details, so we can investigate your claim.

\section{OPEN ACCESS}


ESID Working Paper No. 09

Delivering effective social assistance:

Does politics matter?

Armando Barrientos ${ }^{1}$ and Sony Pellissery ${ }^{2}$

${ }^{1} \mathrm{BWPI}$, University of Manchester, UK

${ }^{2}$ Institute of Rural Management, Anand, India

Email correspondence: a.barrientos@manchester.ac.uk)

ISBN number: 978-1-908749-02-4 


\begin{abstract}
The paper examines the significance of politics in the rise of social assistance programmes in developing countries in the last decade. It finds this is a two-way process. Politics is crucial to the adoption, design and implementation of social assistance programmes. They also have a feedback effect on local and national politics. The paper develops a framework for distinguishing the different dimensions of influence. It applies this framework to study the development of social assistance in India, Brazil and South Africa. It employs a comparative perspective to identify key approaches, findings, and knowledge gaps in the politics of social assistance.
\end{abstract}

\title{
Keywords
}

India, Brazil, South Africa, social assistance, poverty, politics, Bolsa Familia, Bolsa Escola, NREGA

\section{Contents}

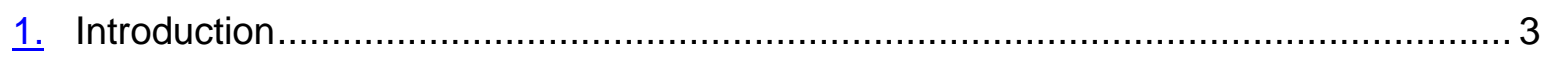

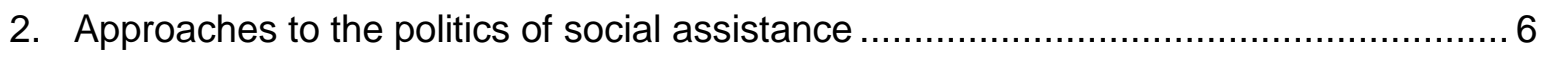

3. Comparative analysis of the politics of social assistance ....................................... 11

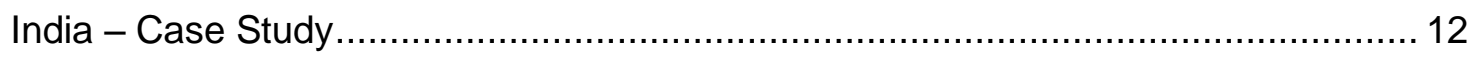

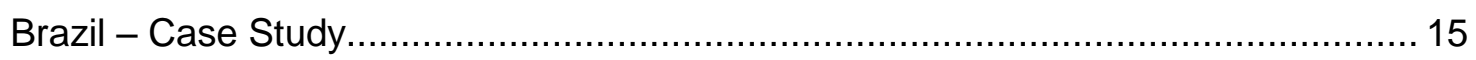

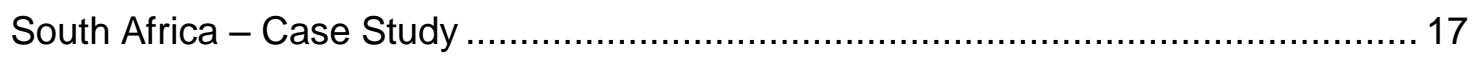

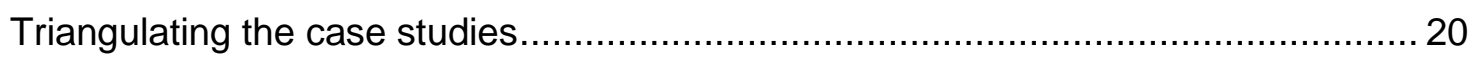

4. Discussion: Does politics matter? .............................................................. 24

Does politics matter for the delivery of effective social assistance?......................... 24

Key approaches, knowledge, and knowledge gaps ......................................... 26

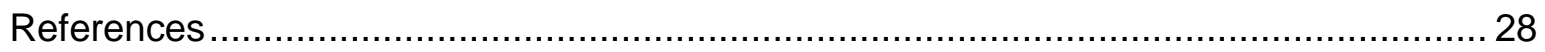




\section{Introduction}

A large expansion of social assistance programmes has taken place in developing countries in the first decade of the $21^{\text {st }}$ century. Large scale antipoverty transfer programmes providing direct transfers to households in poverty have spread to a majority of middle income countries in the South. In low income countries, the growth of social assistance has been slower and more speculative, due in part to delivery capacity and financial constraints. Impact evaluation studies indicate that, taken as a whole and in combination with economic growth and basic service infrastructure, well designed antipoverty programs can make an important contribution to the reduction of global poverty and vulnerability. ${ }^{1}$ Social assistance has become an important component of poverty reduction and development strategies in the South. There is a fast growing literature on antipoverty transfer programmes in developing countries. ${ }^{2}$ To date, the focus of this literature has been on issues of design and impact. It is widely acknowledged that politics does matter for the adoption, design, and implementation of antipoverty transfer programmes, but this remains a substantially under-researched topic. ${ }^{3}$ The main objective of this paper is to review and assess the scarce literature on the politics of social assistance, with a view to identifying relevant approaches, knowledge, and knowledge gaps. Our paper addresses the question of whether politics matter for the delivery of effective social protection in developing countries.

There is a degree of uncertainty around terminology in the context of international development. It will be helpful to start with some definitions. ${ }^{4}$ Social policy includes the provision of basic services - in the main education and health care, but also water and sanitation in low income countries - and social protection. Social protection includes three main components: social insurance, social assistance and labour market interventions. Social insurance covers contributory programmes covering life course and work related contingencies. Social assistance comprises tax-financed programmes managed by public agencies and addressing poverty and deprivation. It has become commonplace to distinguish 'passive' from 'active' labour market policies, with 'passive' interventions aimed at securing basic rights in the workplace and 'active' interventions enhancing employability.

Our paper focuses on social assistance or antipoverty transfer programmes, that is, taxfinanced programmes directed by public agencies with the objective of reducing, preventing, and eventually eradicating poverty (Barrientos, 2007). Programmes in low income countries are sometimes financed from international assistance. They are tax-financed but the taxes are collected in a different jurisdiction.

\footnotetext{
${ }^{1}$ They can also make a marginal contribution to the reduction of inequality. A recent cross-country study on declining inequality trends in Latin America identifies two main explanations: (i) a fall in the premium to skilled labour, (ii) the impact of higher and more progressive government transfers. See López-Calva, L. F. and Lustig, N. (eds.) 2010. Declining Inequality in Latin America: A decade of progress?, Washington DC: Brookings Institution and UNDP.

${ }^{2}$ See Fiszbein, A. and Schady, N. 2009. Conditional Cash Transfers. Reducing Present and Future Poverty, Washington DC: The World Bank; Grosh, M., Del Ninno, C., Tesliuc, E. and Ouerghi, A. 2008. For Protection and Promotion. The Design and Implementation of Effective Safety Nets, Washington DC: The World Bank; Hanlon, J., Barrientos, A. and Hulme, D. 2010. Just give money to the poor. The Development revolution from the South, Sterling VA: Kumarian Press.

${ }^{3}$ See Hickey, S. 2008. Conceptualising the politics of social protection in Africa. In: Barrientos, A. and Hulme, D. (eds.) Social Protection for the Poor and Poorest: Concepts, Policies and Politics. London: Palgrave.

${ }^{4}$ Uncertainty over terminology and scope is greatest in international policy debates.
} 
There is huge diversity in the design of social assistance in developed and developing countries. In high income countries, social assistance has an income maintenance design, providing income transfers aimed at filling in the poverty gap. In developing countries ${ }^{5}$, social assistance includes a variety of programme design, including pure income transfers, as in non-contributory pensions or child grants and allowances; income transfers combined with asset accumulation and protection, as in human development conditional transfer programmes or guaranteed employment schemes; and integrated antipoverty programmes covering a range of poverty dimensions and addressing social exclusion. There is also diversity in scale, scope and institutionalisation in social assistance across countries, and across programmes within countries.

The focus of the paper is on the politics of social assistance in developing countries. This involves examining a two way process. On the one hand, social assistance is shaped by political processes. The extension of antipoverty transfer in the South reflects growing attention to poverty reduction. In many countries in the South, social policy, but particularly social protection and assistance, has risen in importance in political and policy discourse and debate. Lula's re-election in 2006 is credited by many to the success of Bolsa Familia. ${ }^{6}$ In India, the re-election of the United Progressive Alliance (UPA) in 2009 is largely credited to the introduction of NREGA in their first term. ${ }^{7}$ The first important set of issues and questions revolve around the influence of politics on the shape of social assistance in the South. On the other hand, social assistance programmes feed back into politics at the national and local levels. Social assistance programmes have the potential to enhance the political participation of groups in poverty at the local level, align electoral support, and change policy priorities and the effectiveness of service delivery. ${ }^{8}$ At the national level, social assistance programmes have the potential to lock in left of centre or populist coalitions, and perhaps generate wider changes in policy. A discussion of these feedback processes would throw light upon potential issues of dependency and political manipulation by elites. A second important set of questions and issues revolve around the significance and orientation of these feedback processes.

The existing literature on the politics of social assistance is scarce and country- or programme-specific. A full review of the literature will not be attempted here, but relevant studies will be referred to and integrated throughout the paper. There is a fast and growing literature focusing on the micro-level interaction of social assistance and politics. This literature is country- or programme specific. ${ }^{9}$ There is a scarce literature examining the

\footnotetext{
${ }^{5}$ See Barrientos, A., Niño-Zarazúa, M. and Maitrot, M. 2010. Social Assistance in Developing Countries Database Version 5, Report Manchester: Brooks World Poverty Institute. Available from http://papers.ssrn.com/sol3/papers.cfm?abstract id =1672090

${ }^{6}$ See e.g. Zucco, C. 2008. 'The President's 'New' Constituency: Lula and the Pragmatic Vote in Brazil's 2006 Presidential Elections'. Journal of Latin American Studies, 40: 29-49.

${ }^{7}$ Yadav, Y. and Palshinkar, S. (2009) "Between Fortuna and Virtu: Explaining the Congress' Ambiguous Victory in 2009" Economic and Political Weekly 44 (39).

${ }^{8} \mathrm{~A}$ good case in point is NREGA introduction in India. With the introduction of the programme, poor people got opportunity to interact at the sites of work location, and to organize themselves as 'NREGA workers'. Some state governments facilitated this potential opportunity to bring accountability in the work systems and to improve governance by using the feedback from the NREGA workers (Pellissery, S. and Jalan, S. (2011) "Towards transformative social protection" Gender and Development 19 (2) pp. 284-93).

${ }^{9}$ See for example de la O, A. L. 2006. Do Poverty Relief Funds Affect Electoral Behaviour? Evidence from a Randomized Experiment in Mexico, Mimeo Cambridge MA: MIT; Giovagnoli, P. 2005. Poverty Alleviation or Political Networking? A combined qual-quant analysis of the implementation of safety nets in post crisis Argentina, 05-66, London: DESTIN, London School of Economics; Zucco, C. 2008. 'The President's 'New' Constituency: Lula and the Pragmatic Vote in Brazil's 2006 Presidential Elections'. Journal of Latin American
} 
macro- or structural political factors facilitating or restricting social assistance. ${ }^{10}$ The most significant gap in the literature relates to conceptual frameworks capable of explaining the politics of poverty reduction programmes. The existing literature draws from the conceptual frameworks developed to study the politics of redistribution. ${ }^{11}$ This framework provides interesting insights, but there are few gains in collapsing processes of poverty reduction into processes of redistribution. For high income countries, Esping-Andersen has provided the most influential framework for examining the production of welfare in advanced capitalist countries, ${ }^{12}$ but efforts to adapt the framework to the examination of developing countries have not paid sufficient attention to politics or social assistance.

Given the vast ground to be covered and the absence of comprehensive approaches to the issue under investigation, it is important to set out the approach and methodology adopted in the paper at the outset. It is beyond the scope of the paper to try to cover all programmes, countries, and regions. It is necessary to be extremely selective on these. Our paper will focus on three countries: Brazil, India, and South Africa. The justification for selecting these three countries is straightforward. They are three large middle income countries with a rich experience of social assistance innovations. They are leading countries in their region. Together, they provide a range of approaches to the extension of social assistance and also demonstrate the diversity of political institutions. The country selection will inevitably influence the discussion in the paper. It can be argued that the three countries selected have conditions which have led to a rapid growth in social assistance, conditions which are hard to replicate elsewhere. The point of the country selection is to learn about the role of politics in social assistance, not necessarily to ensure representativeness of conditions in the South. The analysis in the paper will provide insights and perspectives valuable to other developing countries, and the framework presented in the paper should enable one to assess the strength and weaknesses of the relevant institutions and to identify feedback effects from, and to, political processes in those contexts.

Our methodological approach will be twofold. A comparative study of the politics of social assistance in the three countries selected will help identify inductively key issues and questions. This will be preceded by a discussion of how best to model the interaction of politics and social assistance in developing countries. This discussion will help give shape to the main features of an appropriate deductive framework. A process of triangulation will help achieve the main objectives of the paper: to identify key approaches, findings and knowledge gaps.

The rest of the paper is divided into three main sections. Section 2 introduces and discusses a framework for examining the politics of social assistance. Section 3 presents the main

Studies, 40: 29-49; Pellisery, S. 2008. Process deficits in the provision of social protection in rural Maharashtra. In: Barrientos, A. and Hulme, D. (eds.) Social Protection for the Poor and Poorest: Concepts, Policies and Politics. London: Palgrave.

${ }^{10}$ See Hickey, S. Ibid.Conceptualising the politics of social protection in Africa; Hickey, S. 2009. 'The politics of Protecting the Poorest: Beyond the Anti-Politics Machine'. Political Geography, 28: 473-483.

${ }^{11}$ See for a recent survey Robinson, J. A. 2010. The Political Economy of Redistribution. In: López-Calva, L. F. and Lustig, N. (eds.) Declining inequality in Latin America. A decade of Progress? Washington DC: Brookings Institution Press. The classic source is Meltzer, A. M. and Scott, R. F. 1981. 'A rational theory of the size of government'. Journal of Political Economy, 89: 914-927.

12 Politics and social assistance played a larger part in his earlier work. See Esping-Andersen, G. 1990. The Three Worlds of Welfare Capitalism, Cambridge: Polity Press. Attempts to adapt the framework to developing countries have focused on institutions, and ignored politics. See Gough, I. and Wood, G. (eds.) 2004. Insecurity and welfare regimes in Asia, Africa and Latin America, Cambridge: Cambridge University Press. 
findings from the three country case studies and draws out the main differences and similarities. Section 4 goes back to the main research question and discusses whether politics matter for the growth and effectiveness of social assistance in developing countries, and draws out the main conclusions.

\section{Approaches to the politics of social assistance}

As noted there is scarce literature on the politics of social assistance. By far the most widely used approach assumes a situation in which politicians compete for support among voters, and voters exercise preferences in line with their interests and advantage. Politics in this context has the function of aggregating voter preferences. ${ }^{13}$ In conditions of an inclusive franchise and a single issue policy, the preferences of the median voter signal the direction of policy. Applying this perspective to social assistance would suggest that highly unequal societies with high poverty incidence would opt for more generous forms of social assistance. ${ }^{14}$ In conditions where low income groups are a minority, coalitions including the middle classes would be required to support greater expenditure on broad-based social assistance. ${ }^{15}$ Social assistance would be weakest in conditions of greater equality and low poverty incidence. These predictions are at odds with the facts of the expansion of social assistance in developing countries, and fail to explain both its timing and scale.

An issue is that several features of political systems in developing countries differ from the assumptions of the median voter model. Political competition is imperfect in situations where the franchise is restricted, or where patrimonial or identity politics filter the aggregation of preferences in favour of elites. In these contexts, politics reflects more directly the concentration of power and influence as opposed to the calculated preferences of the population. The greater the concentration of wealth and power, the weaker will be the policies addressing poverty. In situations where identity politics dominate, the design and implementation of social assistance is likely to be fragmented and unequal. ${ }^{16}$ Imperfect political competition gives greater autonomy to politicians representing powerful interests and elites.

The role of public agencies charged with implementing social programmes becomes more significant after programmes are legislated for and adopted. The degree of autonomy of civil servants, and the nature of their linkages to political elites, can have implications for the reach and effectiveness of social assistance programmes (Alesina and Tabellini, 2004; Besley and Ghatak, 2007; Mookherjee, 2004). In particular, in countries with federal structures, the links between public agencies and local politicians is of some significance for the evolution and implementation of these programmes. (Giovagnoli, 2005).

\footnotetext{
13 "What institutions or policies a political system generates depends on the distribution of power in society and how political institutions and mobilized interests aggregate preferences" (p.39) Robinson, J. A. 2010. The Political Economy of Redistribution. In: López-Calva, L. F. and Lustig, N. (eds.) Declining inequality in Latin America. A decade of Progress? Washington DC: Brookings Institution Press.

${ }^{14}$ See Alesina, A. 1999. Too Large and too Small Governments. In: Tanzi, V., Chu, K.-y. and Gupta, S. (eds.) Economic Policy and Equity. Washington DC: International Monetary Fund.

${ }^{15}$ Gelbach, J. B. and Pritchett, L. 1995. Does more for the poor mean less for the poor? The politics of targeting, Policy Research Working Papers 1799, Washington DC: The World Bank.

${ }^{16}$ See Keefer, P. and Khemani, S. 2003. The Political Economy of Public Expenditures, Mimeo Washington DC: The World Bank.
} 
Even this brief discussion highlights the complexity of the political influences over social assistance and the variety of potential approaches to studying these influences. Small variations in political structures can have large effects on the direction and relative weight of the predicted effects.

To address this complexity, the paper develops a phased approach to this issue. Figure 1 below provides a summary. The framework presented in Figure 1 should be approached as a means of separating out the different dimensions of social assistance to highlight the political influences specifically relevant to a specific dimension. The most productive way of approaching the framework as an analysis tool is to imagine the different columns as sections of a concertina. In practice it is hard to separate out the different political influences on social assistance, and their variation across countries and across time, but by extending the concertina, it is possible to highlight the political issues of greatest relevance in specific dimensions. Once that work is done, it becomes possible to bring all the influences together.

The first two rows define which political factors are included and excluded. The first column assumes direct democracy, voters exercise their preferences directly through the political process. Political representatives, government, and civil society are assumed to follow voter preferences. They have no influence over decision making. The main function of the political process is to aggregate voter preferences. This simple account of the political process is relevant to the adoption of social assistance strategies and programmes. The clearest examples of direct democracy in shaping social assistance arise in contexts where social contracts are being renewed. The new 1988 Constitution in Brazil, for example, was the outcome of a popular decision at the end of twenty years of dictatorship from 1965 to 1985, to reconsider the basis for citizenship in the country. The Constituent Assembly discussions led to the inclusion of a right to social protection based on citizenship, as opposed to the contributory principle which had dominated the development of social insurance. ${ }^{17}$ The right to social protection based on a citizenship principle has become embedded in government policies aimed at securing a minimum guaranteed income for all residents in Brazil. ${ }^{18}$ This provided the basis for the expansion of social assistance in Brazil. In fact a procedural definition of a social contract can be described in terms of the intervention of direct democratic processes. In practice, single event social contracts, like the Brazilian experience, are rare. Social pacts and dominant coalitions might lead to the same policy outcomes, but without the presence of direct democracy. ${ }^{19}$

The important point about direct democracy and the extension of social assistance is this: where political processes revert to the simple function of aggregating preferences, social assistance institutions are likely to emerge. Of course, social assistance can also emerge in conditions where direct democracy conditions are absent. It would be interesting to consider the implications from this point of departure, both in terms of design and scale. ${ }^{20}$ This will

\footnotetext{
${ }^{17}$ For a discussion of the citizenship and contributory principles in the context of social protection and the social security reforms in the 1980s in the UK, see Plant, R. 2003. 'Citizenship and social security'. Fiscal Studies, 24: 153-166.

${ }^{18}$ See Mesquita, A. C. S., Jaccoud, L. and dos Santos, M. P. G. 2010. Garantia de Renda na Política Social Brasileira: Entre a Proteçao aos Riscos Sociais e o Alivio à Pobreza, Mimeo Brasilia: IPEA.

${ }^{19}$ The 'War on Poverty' in the USA in the 1970s or the building of welfare states in European countries in the post-second World War period provide examples of an expansion of social assistance based on the emergence of a broad consensus across governing coalitions but without originating in a single-event. Rawls's 'veil of ignorance' is an abstract construct which can be interpreted as a counterpart to direct democracy. See Rawls, J. 1971. A Theory of Justice, Cambridge, MA: Harvard University Press.

${ }^{20}$ This applies to the distinction between Bismarckian and Beveridgean social security, for example.
} 
involve collecting and evaluating single events leading to the expansion of social assistance. In the context of the development of social assistance in low income developing countries, the role of international partners adds a complication to the aggregation of preferences with important implications for social assistance outcomes in these countries

The second column, entitled representative democracy, envisages preference aggregation through political representatives. This ensures a focus on attracting and sustaining electoral support. The priority given to antipoverty policy then plays within the political processes selecting representatives and endowing their decisions with legitimacy. This level of abstraction is particularly relevant to issues around the design, reach and incidence, and budget setting for social assistance programmes. The last two are intimately related. In most developing countries, parliamentarians set the budget for antipoverty programmes with direct implications for the scale of the programmes. 
Figure 1. An incremental framework for understanding the influence of politics on social assistance in developing countries

\begin{tabular}{|c|c|c|c|c|}
\hline & \multicolumn{4}{|c|}{ Adding complexity incrementally------------------ $\rightarrow$} \\
\hline & Direct democracy & Representative democracy & $\begin{array}{l}\text { Representative democracy } \\
\text { with a measure of } \\
\text { government autonomy }\end{array}$ & $\begin{array}{l}\text { Representative democracy with a } \\
\text { measure of government autonomy } \\
\text { and participation }\end{array}$ \\
\hline $\begin{array}{l}\text { What does the analysis } \\
\text { abstract from? }\end{array}$ & $\begin{array}{l}\text { Representatives } \\
\text { Government } \\
\text { Civil society }\end{array}$ & $\begin{array}{l}\text { Government } \\
\text { Civil society }\end{array}$ & Civil society & \\
\hline $\begin{array}{l}\text { What political influences } \\
\text { are included? }\end{array}$ & Democratic process & $\begin{array}{l}\text { Democratic process } \\
\text { Representatives }\end{array}$ & $\begin{array}{l}\text { Democratic process } \\
\text { Representatives } \\
\text { Government }\end{array}$ & $\begin{array}{l}\text { Democratic process } \\
\text { Representatives } \\
\text { Government } \\
\text { Civil society }\end{array}$ \\
\hline Focus points/areas & Preference aggregation & $\begin{array}{l}\text { Social assistance and electoral } \\
\text { support } \\
\text { Priority of antipoverty policy }\end{array}$ & $\begin{array}{l}\text { Decentralisation/centralisation } \\
\text { Process deficits - Fiduciary risk }\end{array}$ & $\begin{array}{l}\text { Accountability } \\
\text { Public support } \\
\text { Interest groups }\end{array}$ \\
\hline $\begin{array}{l}\text { Key social assistance } \\
\text { dimension }\end{array}$ & Adoption & Design, incidence, and budget & Implementation & $\begin{array}{l}\text { Accountability } \\
\text { Dynamics: e.g. Growth (+ or -) }\end{array}$ \\
\hline $\begin{array}{l}\text { Practical issues/findings } \\
\text { relevant to social } \\
\text { assistance }\end{array}$ & $\begin{array}{l}\text { Adoption of antipoverty } \\
\text { strategies, programmes or } \\
\text { policies }\end{array}$ & $\begin{array}{l}\text { Design } \\
\text { Reach/incidence } \\
\text { Budgets } \\
\text { Leading agency }\end{array}$ & $\begin{array}{l}\text { Beneficiary selection } \\
\text { Transfer level and type } \\
\text { Coverage } \\
\text { Horizontal and vertical } \\
\text { coordination } \\
\text { M\&E }\end{array}$ & $\begin{array}{l}\text { Forms of accountability } \\
\text { Participatory processes }\end{array}$ \\
\hline Key political issues & $\begin{array}{l}\text { Social contract - which can be } \\
\text { understood as the point at } \\
\text { which direct democratic } \\
\text { processes operate } \\
\text { Social pacts? Coalitions? } \\
\text { Influence of donors in LICs }\end{array}$ & $\begin{array}{l}\text { Building and maintaining } \\
\text { coalitions } \\
\text { Ideology and policy preferences } \\
\text { Basis for electoral advantage } \\
\text { Competitive versus identity politics } \\
\text { Opportunities for reform/ scale up }\end{array}$ & $\begin{array}{l}\text { Federal/Estate/District politics, } \\
\text { respective roles, responsibilities, } \\
\text { and gains } \\
\text { Strengthening technical and } \\
\text { political networks coalitions } \\
\text { Public perceptions of } \\
\text { effectiveness and sustainability of } \\
\text { political support } \\
\text { Elections and opportunities for } \\
\text { change and reform } \\
\text { Closed or open source models as } \\
\text { far as lower instances }\end{array}$ & $\begin{array}{l}\text { Political sustainability } \\
\text { Managing political change (changes in } \\
\text { government, etc) } \\
\text { Coalition building } \\
\text { Feedback into political processes }\end{array}$ \\
\hline
\end{tabular}


There are specific features of political processes which have particular relevance at this level of abstraction. The need to build and sustain coalitions often influences the scale and location of antipoverty transfer programmes, as well as the distribution of programme budgets. ${ }^{21}$ Historically, rural interests and their representatives show a preference for broadbased, tax-financed programmes, while urban interest and their representatives have a preference for occupational employment-related social insurance plans. ${ }^{22} \mathrm{~A}$ specific issue in this context is how to explain the fact that selective antipoverty transfer programmes could secure a broad base of political support in some developing countries. Identity politics can help sustain and enlarge social assistance programmes in some countries like South Africa or India, but limit them in other contexts, as in ethnically divided low income countries in Sub-Saharan Africa. The issue of electoral advantage arising from the perceived effectiveness of social assistance is also an interesting issue at this level of abstraction.

The third column takes account of the degree of autonomy of public agencies. ${ }^{23}$ This level is particularly relevant to issues of implementation and scaling up of antipoverty transfer programmes. The degree of autonomy of public agencies is essential to understand the operation of social assistance in the context of decentralised political and programme structures. In many low income countries, process deficits and fiduciary risks are very significant and strongly influence the scale and scope of antipoverty transfer programmes. In the context of transfers which are combined with asset accumulation or protection or in the case of antipoverty programmes, horizontal and vertical coordination is central to the effectiveness of the programmes. Monitoring and evaluation processes provide measures of effectiveness and impact.

The features of the political processes which are important at this level include the linkages between different levels of government and the distribution of political influence and power. In highly centralised countries, the responsibility and political gains for a social assistance programmes are located at the federal or central government level; whereas in countries with a decentralised administrative and political structure, the distribution of responsibility and potential electoral gains are outcomes from interlinked processes. These imply the need to pay attention to public perceptions of the effectiveness of the programmes to a greater extent than where programmes are heavily centralised. The relative autonomy of public agencies grants a stronger influence on technocratic networks.

The final column incorporates civil society organisations and their political influence. In developing countries, civil society organisations have not had a strong influence on social assistance growth. Trade unions and employers, for example, have not been directly affected by the extension of the programmes. ${ }^{24}$ Community and Non-Governmental Organisations in some countries are mainly involved in ensuring the rights of potential beneficiaries and managing processes of accountability of programme managers. Their engagement has some implications for the reform and extension of programmes.

\footnotetext{
${ }^{21}$ See de Janvry, A., Nakagawa, H. and Sadoulet, E. 2009. Pro-poor targeting and electoral rewards in decentralizing to communities the provision of public goods in rural Zambia, Mimeo Berkeley: University of California at Berkeley; Giovagnoli, P. 2005. Poverty Alleviation or Political Networking? A combined qual-quant analysis of the implementation of safety nets in post crisis Argentina, 05-66, London: DESTIN, London School of Economics.

${ }^{22}$ See for example the origins of the Swedish pension system.

${ }^{23}$ By autonomy we understand the extent to which public agencies can influence the shape of social assistance in line with their own particular preferences or interests.

${ }^{24}$ Private sector employers of agricultural labour in India are probably an exception. The National Rural Employment Guarantee in India has helped raise market wages in this sector.
} 
As noted above, the most productive way to apply this framework as an analytical tool is to imagine the different columns as parts of a concertina. Extending the concertina enables an analysis of the different political influences on social assistance, which need to be brought together at a second stage. Two additional points on the framework are important. Firstly, the framework assumes that national politics are dominant in terms of their influence on antipoverty programmes. This can be contentious because we find below that local politics sometimes overrides national politics in the context of social assistance. In Brazil, we find local level dynamics more clearly. In India too, state level primacy for the emergence of social assistance is clear. In India, separating out design and implementation, gives then local level politics an overriding importance at the implementation stage Local level politics might need to be examined separately and then integrated within the national level. However, our approach to give primacy for national level politics is important since we are attempting to find a workable model beyond the case countries presented here. Federal institutions have to be treated as context variables that will bring changes to the model presented. International political influences, for example through the Millennium Development Goals or through regional commitment and policy diffusion, have not been fully incorporated into the model, except through their influence at the national level. ${ }^{25} 26$ Secondly, the framework does not specifically address any potential political influences over the dynamics of social assistance, except through issues of scale. It will be important in this context to pay special attention to social assistance as a whole as opposed to particular programmes. The political influences on the institutionalisation of social assistance programmes are an important research issue.

The revenue side of the framework is in many respects crucial, both to the shape and scale of social assistance, and to the quality of the political linkages. For example, there are good reasons to hypothesize that those governments able to rely on revenues from natural resources might have a greater degree of autonomy from voters in the design of policy than governments reliant on direct taxation. The extent to which revenues are centralised or dispersed in deferral political systems largely defines the relative influence on the different levels of government and politics. Including the revenue side would require a significantly larger paper, but perhaps not a great deal of change to the framework developed above. Whilst highlighting the importance of the revenue side, this is left out of discussion below.

\section{Comparative analysis of the politics of social assistance}

This section focuses on case studies constructed to map out and analyse the political dimension of social assistance growth in three countries: India, Brazil and South Africa. The

\footnotetext{
${ }^{25}$ Global social policy approaches give international organisations a dominant role. See Deacon, B. 1997. Global Social Policy. International organizations and the future of welfare, London: Sage.

${ }^{26}$ Regional influences might be significant in certain contexts, especially where clusters of specific types of programmes can be observed at the sub-regional level. In Southern Africa, pure transfers to groups considered to be in acute vulnerability are dominant, especially non-contributory pensions and child grants. See Devereux, S. 2007. 'Social Pensions in Southern Africa in the Twentieth Century'. Journal of Southern African Studies, 33. Human development transfer programmes are dominant in South America. See Cecchini, S. and Martínez, R. 2011. Protección social inclusiva en América Latina: Una mirada integral, un enfoque de derechos, Santiago: CEPAL.
} 
main findings are discussed below, more detail can be found in Annex 1 at the end of the paper.

\subsection{India - Case Study}

Introduction of social assistance in India can be traced back to British colonial legacy. ${ }^{27}$ On the one hand formal social security was introduced for employees in the formal sector after the European model. In effect, this was divisive, as the well-off sections employed in regular jobs were able to gain the welfare benefits, and close to $90 \%$ of the labour force (primarily in agriculture sector) was excluded from the same. On the other hand, in its low growth period until the early 1990s, central government paid little attention to this issue and largely development, particularly rural development, was the focus. These anti-poverty programmes aimed to provide food and nutrition, ${ }^{28}$ provide basic services like education, health care and housing, generate employment through public works programmes ${ }^{29}$ and improve natural resources and rural people's assets through Integrated Rural Development Programmes. ${ }^{30}$ Anti-poverty programmes, as emerging from the nation-building discourse, dominated the politics of social assistance. ${ }^{31}$

The Constitution of India had left the issue of social assistance as 'desirable activity' under its directive principles. Therefore, federal states (formed according to the regional languages after independence in 1947) undertook initiatives to introduce social security measures. The state of Uttar Pradesh introduced the earliest programme of old age pension in $1957 .{ }^{32}$ Different states began to introduce different programmes such as pension for agricultural landless labourers, maternity benefit, disability benefit, relief for educated unemployed persons and employment guarantee depending on the 'need' for the same in respective states. Thus, paternalistic and patrimonial principles dominated the origin of these programmes more so than right to welfare or justice principles (p.39) (Jayal, 2001). Very often, these programmes were also introduced as electoral instruments, with the name of the programme prefixed with a politician's name, which would signal who should be credited for such a programme. These state level programmes were aimed at workers in informal sector, primarily agricultural workers on whom the political class relied for votes. In important way welfare regimes in India could be classified as 'clientelist' or 'populist'. A couple of exceptional states had the influence of left-leaning politics to demand social assistance (Harriss, 2004).

\footnotetext{
${ }^{27}$ For a long view, see Osmani, S. R. 1991. Social Security in South Asia. In: Ahmad, E., Drèze, J., Hills, J. and Sen, A. (eds.) Social Security in Developing Countries. Oxford: Clarendon Press.

${ }^{28}$ The largest of the programmes, the Public Distribution System, which distributes essential food items and nonfood items (e.g. Kerosene) through a network of fare (fair??) price shops, incurred expenses close to $1 \%$ of GDP primarily as subsidy. This was largely untargeted until 1990s. Apart from this, specific nutritional programmes for children and pregnant women were in place under an umbrella programme of Integrated Child Development Scheme (ICDS).

${ }^{29}$ Since the 1960s large number of public works programmes which provided cash or kind in exchange of labour was a predominant mode of relief especially in times of drought in rural areas.

${ }^{30}$ These sets of programme were initiated in 1952 and the community was taken into confidence while designing what kind of programme could bring developmental changes. Thus, intervention varied from providing assets such as milk animals, to improving dry land, to providing market linkage or finance for small business.

${ }^{31}$ There is considerable scholarship that has analysed the relationship between the advantage for political class through the introduction of such anti-poverty programmes. See for instance,, among others, Kohli, A. 1989. The State and Poverty in India, Cambridge: Cambridge University Press.(1987); and Harriss, J. 2004. How much difference does politics make? Regime differences across Indian states and rural poverty reduction, Destin Working Paper 1, London: LSE DESTIN.

${ }^{32}$ See for a list of year of introduction of the programme and different states where they were introduced, Dev, M. 1998. Government interventions and social security for rural labour In: Radhakrishna, R. and Sharma, A. N.

(eds.) Empowering Rural Labour in India. New Delhi: Institute for Human Development.
} 
In the last two decades, there is a reversal of the story. Central government has enacted a number of social assistance measures by systematically expanding the fundamental rights (such as the right to life, the right to employment etc.) enshrined in the constitution of India. From the social assistance viewpoint, three developments are important. First, in 1995 Central government introduced the National Social Assistance Programme (NSAP), under which five different benefits were provided, which complimented what federal states were already providing. These benefits were Old Age Pension Scheme (reaching $8.3 \%$ of elderly households), Widow Pension Scheme (6.2\% of widow households), Disability Pension Scheme (reaching $14.1 \%$ of disabled households), Family Benefit Scheme (one-time relief for the families where main breadwinner accidently died) and Annapurna (food for the elderly households). ${ }^{33}$ What triggered this development is very closely tied to the story of liberalisation that India followed since 1991. Social sector expenditure for the period 19911995 showed a distinct decline in state expenditure, primarily since the Centre's aggregate transfer to states got reduced (Guhan, 1994; Prabhu and Chatterjee, 1993; Guhan, 1995) in the process of state retrieval. This provided an opportunity for bureaucratic-civil society entrepreneurs to argue for direct transfer through initiating social assistance programmes. Introduction of the programme in proximity to the next general election and prefixing of the schemes with the name 'Indira Gandhi' are worth noting. These programmes were meant for poor households. The identification process for poor households took place every five years, which has been much politically contested both locally ${ }^{34}$, and between the federal state and central government in determining the threshold of number of poor people in a state, since that determines the quota of transfer from the Centre to the state. The poor households, identified through the survey, classified as 'Below Poverty Line' (BPL) is eligible for different NSAP programmes. Often, concentration of poverty in particular social categories helped to create a clientelist politics of its own through this targeted approach.

Both the second and third important developments take place in 2004 when the Congress Party government had been voted to power in a coalition with Left parties. A wider civil society movement that pressed for food security gets significant policy voice through civil society actors who were appointed as members of National Advisory Council. This civil society activism was successful in getting the bill enacted by parliament in 2005 for the Employment Guarantee Act that ensures 100 days of employment for every rural household. ${ }^{35}$ The programme reaches approximately 33 percent of rural households. Unlike the National Social Assistance Programme of 1995, this was legislated as a right and parliamentary scrutiny was very high. Left parties, being in coalition, also had pressed for social security programmes for the vast majority of unorganised sector workers. Eventually, in 2009 a Social Security Board was legislated. The health insurance programme (Rashtriya Swasthya Bhima Yojana), designed particularly for the workforce in the unorganised sector, has already provided insurance against hospitalisation for 40 million households.

A key challenge faced when all social assistance programmes were introduced has been the assertion from right wing advocates that social assistance expenditure is both ineffective and

\footnotetext{
${ }^{33}$ The figures for reach are based on the World Bank 2011 Social Protection for Changing India, Report. Washington: The World Bank. General evaluation of these programmes is that though the benefits are small, it makes big difference to the households Dutta, P., Howes, S. and Murgai, R. 2010. 'Small but effective: India's targeted unconditional cash transfers'. Economic and Political Weekly, 65: 63-70.

${ }^{34}$ See Hirway, I. 2003. 'Identification of BPL households for poverty alleviation programmes'. Ibid.38: 4803-4838.

${ }^{35}$ It is important to note that the prefix of 'Mahatma Gandhi' was introduced to the programme after the government was voted to power without coalition forces, particularly Left parties in 2009.
} 
wasteful. The inequality discourse has been effective in countering such positions. The growth story of India has widened inequality rather than bridging the gap. Therefore the introduction of social assistance would be helpful as an inclusive instrument for the poorer sections of the population. Socio-economic divisions within the country demanded programmes that could create support from across different sections. For instance, the NREGA programme has been devised to provide labour for wage seeking households during the lean agricultural season, without harming the landlord-labourer relation. However, when the agricultural wages rose, landlords showed resistance to NREGA itself. At the same time since the NREGA programme improves community infrastructure such as roads or irrigation facilities this acted as an incentive for landlords. Tax payers in urban areas were allured with the promise that when rural household were provided with employment in the villages, they would refrain from migration, bringing ease to the already hugely pressured urban infrastructure (Ambasta et al., 2008; MacAuslan, 2008).

Lower levels of administration such as district or village government, although elected bodies, enter into the politics of social protection when the programmes are being implemented. In the interpretation of eligibility criteria or selection of beneficiaries, local politics play critical role (Raabe et al., 2010; Shankar et al., 2011). However, in designing the programme and finance, it is the politics at federal level and central government level which matters. Thus, implementation deficits and corruption in the programme indicate an absence of government autonomy from social forces. Introduction of the social assistance programmes hugely shape local politics since local elites act as brokers to facilitate access for the target population. ${ }^{36}$ This ability to satisfy local elites by the national or state level elites through introduction of policies acts as a feedback mechanism.

Acting as a countervailing force to such a nexus between local elites and national elites is the role of NGOs and other civil society institutions. The politics of civil society organisation is primarily about how these organisations are able to score a goal against local politicians and bureaucrats. Therefore, being able to provide access to a social assistance programme, which was denied by a politician or a bureaucrat increases the credibility of an NGO. In the case of NREGA this has come to the fore when social audits conducted by NGOs reached contradictory conclusions to government agencies. In other words, accountability achieved is through the participation of citizens as mediated through civil society organisations (re column four).

Accountability at the central government level is diffused due to an absence of single ministry or autonomous agency in India. There are over 300 different types of anti-poverty schemes spread over 13 different ministries. There is hardly any coherence amongst these programmes. No attempt is made at integration at national level. Often, NGOs have been successful in achieving integration at local level, since they prioritise the needs of the local population and claim for complementary anti-poverty programmes for one particular locality.

\footnotetext{
${ }^{36}$ In many north Indian states, panchayat (village level government) election has become more contested (with more money spent by candidates during election) after the introduction of NREGA since the elected body of panchayat gets to control huge amount of money allocated for NREGA works. A study has shown how selection of workers for NREGA programme is according to the caste lines one respective caste member is elected as head of Panchayat. For same effects on social pensions see Pellisery, S. 2008. Process deficits in the provision of social protection in rural Maharashtra. In: Barrientos, A. and Hulme, D. (eds.) Social Protection for the Poor and Poorest: Concepts, Policies and Politics. London: Palgrave; Pellissery, S. 2005. 'Local determinants of exclusion and inclusion in Rural Public Work Programmes: A political economy approach'. International Journal of Rural management, 1: 167-184.
} 
This has helped NGOs to remain as a sustaining force. On many occasions, the government has taken the help of NGOs to carry out this role in concerted manner throughout the state by creating NGO consortiums. ${ }^{37}$

To sum up, the expansion of social assistance in India through Central government initiatives has to be seen as a process of change management due to economic liberalisation and pressures from left parties for inclusive growth. A wider social contract is still elusive due to identity politics, and linguistic identities are further reinforced by the federal structure. When the same elected political party is in power at both central and state level, there is synergy for social assistance delivery for brief periods.

\subsection{Brazil - Case Study}

Brazil provides one of the most important examples of effective delivery of social assistance in the developing world. ${ }^{38}$ Not only has Brazil introduced important innovations in social assistance, (Bolsa Escola is the precursor of human development transfer programmes in Latin America); and important technological innovations in programme implementation, like the Single Registry; but it has also managed to make a large reduction in poverty over time and also to reduce inequality. More importantly, it has managed this in the context of, until recently, low growth performance. The policy process in Brazil has been intensely political, predominantly in a positive sense. The feedback effects from social assistance are also important, especially in the electoral success of Lula in 2006.

The starting point in tracing the rise of social assistance in Brazil is the 1988 Constitution, which followed a long period of right wing dictatorship from 1965-1985. The Constitution was intended as a new social contract extending citizenship to all. The Constitution enshrined a right to social protection, and led to a rethink of the role and scope of social security and the role of government to provide it. Prior to 1988, the role of government was to support private organisations and NGOs in the provision of social assistance. ${ }^{39}$ The Constitution recognised social assistance for the first time as an area of government responsibility. It also introduced the citizenship principle behind social assistance, access was a right for all Brazilians; in contrast to the dominant contributory principle behind the development of social insurance from the $1920 \mathrm{~s}^{40}$ (re direct democracy column)

The Constitution emphasised assistance to vulnerable groups, in particular older people and people with disabilities living in households in poverty. The Constitutional right led to the reform and expansion of two non-contributory pension schemes, The Previdencia Social

\footnotetext{
${ }^{37}$ The experience of Andhra Pradesh which leads in the implementation of NREGA has a state-wide NGO consortium where regular monthly meetings are held between NGOs and government agencies at state level, district level and sub-district level. This has been instrumental in bringing the synergy between natural resource management and NREGA in the state. On to how this helped to improve food security in the state see Pellissery, S. and Sanju, S. 2011. NREGA to bridge the missing link for food security: Improving the natural resource access for small land holders. In: Mishra, R. K. and Jayashree, R. (eds.) Millennium Development Goals and India: case assessing performance, prospects and challenges. New Delhi: Allied Publishers.

${ }^{38}$ See Barrientos, A. 2011. The rise of social assistance in Brazil, Mimeo Manchester: BWPI.

39 See Jaccoud, L., Hadjab, P. D. E.-M. and Chaibub, J. R. 2009. Assistência social e securança alimentar: Entre novas trajetórias, vehlas agendas e recentes desafíos (1988-2008). In: Diretoría de Etudos e Políticas Sociais (ed.) Políticas sociais: Acompanhamento e análise 17. Brasilia: IPEA; Jaccoud, L., Hadjab, P. D. E.-M. and Chaibub, J. R. 2010. The consolidation of social assistance in Brazil and its challenges, 1988-2008, Working Paper 76, Brasilia: Internaional Policy Centre.

${ }^{40}$ See footnote 15 above.
} 
Rural and the Beneficio de Prestacao Continuada. They had been introduced in a different guise in the 1970s, but with very limited reach and effectiveness. These were re-shaped, expanded and extended. A separate initiative developed from municipal activism, it was grounded on minimum income guarantee proposals combined with education. In 1995 municipalities began to introduce Bolsa Escola, transfers with schooling conditions. Their origins are in proposals for a guaranteed minimum income, again following the lead established in the Constitution, addressing poverty. The Workers Party, and Senator Suplicy the first elected political representative of that Party, campaigned for this policy after the fall of the dictatorship. The proposal was taken up in several municipalities run by Workers Party politicians, but with an important change in connecting direct income transfers with conditions relating to schooling. The view was that without the links to basic services, the transfers would have very little effect in the medium and longer run, and much less policy and political traction. Bolsa Escola is a hybrid minimum income guarantee and human development instrument, whichreflected thinking on the left and centre that income transfers were not sufficient in the context of persistent intergenerational poverty. Bolsa Escola spread to other municipalities and in 1997 the government provided counterpart funding. In 2001 Bolsa Escola became a federal programme. Scaling up during Cardoso's presidency was probably because its Plan Real to address hyperinflation had large short term adverse effects, therefore need to balance it with poverty activism in the short run. This led to scaling up Bolsa Escola and eventually making it into a federal programme.

During the Cardoso administrations in the late 1990s and early 2000's, addressing poverty through direct transfers became the new orthodoxy in part through political competition within the government (e.g. Jose Serra creates the Auxilio Gas to compete with Bolsa Escola), but also competition with the Workers Party. This led to a proliferation of transfer programmes, with overlapping target populations. Together with other federal transfer programmes, it became Bolsa Familia in 2003.

In 2010, the two main non-contributory pension programmes reached about 10 million households with a budget of around $1.5 \%$ of GDP, while Bolsa Familia reaches over 12 million households with a budget of $0.4 \%$ of GDP.

Parliamentary oversight and policy formulation has been a significant feature in Brazil. ${ }^{41}$ Parliament's active role in defining policy initiatives in poverty reduction goes back to the 1991 proposal for a minimum guaranteed income by Senator Suplicy from the Workers Party; since that date several proposed bills and amendments have been presented and discussed in Congress every year. The proposals and amendments cover the spectrum, from right of centre politicians attempting to reduce the scope and reach of Bolsa Familia to left of centre parliamentarians aiming to expand the programme. Few bills successfully become law. Parliamentary activism reflects strong public opinion and interest in social assistance. There is much less parliamentary attention on the non-contributory pension programmes, in large part because their constitutional recognition implies that discretion over their implementation is very limited. Effectively the government is required to provide entitlements to all Brazilians who qualify for the benefits. Budgets simply reflect these entitlements. In the recent past parliamentary attention has several attempts to change the

\footnotetext{
${ }^{41}$ Britto and Soares provide a detailed discussion of the role of Parliament in defining social assistance policy in Brazil, see Britto, T. and Soares, F. V. 2010. Bolsa Família e Renda de Cidadania - um passo en falso?, Mimeo Brasilia: IPEA.
} 
target population, for example by redefining the scope of households for the purposes of defining entitlements, or restricting entitlements to the Previdencia Social Rural to residents in rural areas.

There are three levels of government in Brazil: federal, estate and municipal. In Brazil municipalities are federal agencies with the same standing as the federal institutions. The estate level has not been active in social assistance. The federal government has influence over policy formulation, budgets, and implementation. Relationship between federal agencies and municipalities work through agreements and joint financing. An important federal tool to stimulate quality and performance is a Decentralisation Index, which ranks municipalities according to their effectiveness and performance with implications for the federal financing streaming down. The index is both a carrot and a stick. ${ }^{42}$ It supports municipalities with deficient capacity and penalises underperforming municipalities. The Index is a technocratic response to principal-agent issues, but increasingly modulates the partnership between federal and municipal levels. The Single Registry collects information on all households applying to any social assistance programme; the database enables the selection of beneficiaries and provides information on their progress through time. It also enables a stronger coordination among programme agencies, as it can be accessed by all agencies involved in the programmes.

The federal government allocates a fixed number of places for Bolsa Familia to municipalities. Local politicians and officials are responsible for registering potential beneficiaries. The information is assessed by the federal government and a score for each household determines eligibility. Local politicians and officials have some influence over the implementation of Bolsa Familia, through adding further interventions too Bolsa Familia or raising benefit levels, and also through ensuring the programme is implemented effectives (for example whether they have filled the federal government allocations). The implication is that feedback effects are significant at the local level too. Politicians who can demonstrate effectiveness in implementing Bolsa Familia receive electoral support and recognition.(re third column)

Civil society and NGOs have a limited role in ensuring accountability of the programme at the local level, but the direct political accountability is more significant. (re column four)

It could be argued that the expansion of social assistance in Brazil, and particularly Bolsa Familia, has extended the life of centre left (Cardoso) and left (Lula) ruling coalitions. They are a dominant political force. Importantly, the expansion of social assistance developments has been show to be consistent with fiscal responsibility, and retains a large measure of political support. Perhaps the most significant feedback effect from social assistance to politics is the rise of social policy and social assistance to the top of the political agenda. Poverty reduction has a high profile, and delivers electoral support for pro-poor politicians.

\subsection{South Africa - Case Study}

\footnotetext{
${ }^{42}$ See Lindert, K., Linder, A., Hobbs, J. and De la Brière, B. 2007. The nuts and bolts of Brazil's Bolsa Familia program: Implementing conditional cash transfers in a decentralized context, Social Protection Discussion Paper 0709, Washington DC: The World Bank.
} 
In South Africa, social assistance can be traced back to the 1920s, with the introduction of the non-contributory pension for poor whites. Social assistance followed the European model of developing income transfers for groups of deserving poor facing acute vulnerability, but with the filter of racial politics. Social pensions were restricted to whites initially, but later incorporated Indians and coloureds and then blacks. The conditions of entitlement and benefit levels were differentiated along racial lines, until the mid 1990s when discrimination was abolished..$^{43}$ Over time, the range of direct transfer programmes expanded to include disability and family grants. By the time that the first ANC government came to power in 1994, social assistance was fragmented due to the homelands policy of Apartheid, and acutely under resourced (Lund, 2008).

The fall of Apartheid led to a new Constitution in 1996 which reaffirmed a commitment to social assistance. Section 27 states that "everyone has the right to access to ...(i) social security, including, if they are unable to support themselves and their dependents appropriate social assistance" (Seekings, 2008). The ANC government took steps to review and strengthen social assistance provision. It established the Lund Committee which led to proposals for a Child Support Grant to replace the family maintenance grant. In 1997 the Government also published a White Paper on Social Assistance which stated the objective of replacing poverty relief with a developmental approach to welfare. The Child Support Grant was initially designed to address child malnutrition and was focused on children 0-6 years of age. Over time, it was extended to include children up to 17 years of age. These measures led to a significant expansion of the reach of social assistance grants. ${ }^{44}$ By 2010 , one in every two households had a social assistance beneficiary, and the budget has doubled since 1994 to over 3.5 percent of GDP. Social assistance is the main policy instrument addressing poverty, vulnerability and exclusion in South Africa. The grants are widely perceived to be effective in reducing poverty and vulnerability, to promote social inclusion and equity, and to have facilitated a difficult transition from Apartheid rule.

The politics of the ANC have dominated the expansion of social assistance since 1994 (Nattrass and Seekings, 2001). Initially, the challenge for the ANC government was to manage the transition from Apartheid, while maintaining credible economic policies and fiscal responsibility. The government of national unity which directly followed the fall of Apartheid in 1994 constituted more of a compromise than a political moment akin a social contract. ${ }^{45}$ However several initiatives which strengthened social assistance like the Child Support Grant Proposal, the Constitutional recognition of the right to social assistance, and the White Paper on Welfare Policy developed within a context of wide ranging support for transformation within the parameters of fiscal responsibility.(re: Direct democracy column)

\footnotetext{
${ }^{43}$ See Barrientos, A. 2008. Cash transfers for older people reduce poverty and inequality. In: Bebbington, A. J., Dani, A. A., De Haan, A. and Walton, M. (eds.) Institutional Pathways to Equity. Addressing Inequality Traps. Washington DC: The World Bank; Lund, F. 2008. Changing Social Policy. The Child Support Grant in South Africa, Cape Town: HSRC Press; Seekings, J. 2008. 'Deserving individuals and groups: The post-apartheid state's justification of the shape of South Africa's system of social assistance'. Transformation, 68: 28-52; van der Berg, S. 1997. 'South African social security under apartheid and beyond'. Development Southern Africa, 14: 481-503.

${ }^{44}$ See Woolard, I. and Leibbrandt, M. 2010. The Evolution and Impact of Unconditional Cash Transfers in South Africa, Working Paper 51, Cape Town: University of Cape Town.

${ }^{45}$ The Minister responsible for social assistance in the national unity government was in fact from the National party Lund, F. 1995. 'Changing social policy in South Africa'. Social Policy Review, 7. The National Party and Intakha left the Government of National Unity in 1996
} 
The next significant political debate around social assistance came with the discussions surrounding the Taylor Committee of Inquiry into a Comprehensive System of Social Security for South Africa in early 2000 s. ${ }^{46}$ A proposal for a basic income was receiving a substantial amount of attention from researchers and the trade unions. Intriguingly, the proposal for a basic income was supported by the National Party and the Communist Party. ${ }^{47}$ The arguments for a basic income in South Africa emphasised its advantages as a citizenship instrument, important in the context of the racially segregated South Africa; as well as the more operational advantages of not requiring targeting and complex administrative implementation. The Taylor Committee supported the basic income proposal. The ANC rejected the basic income on three main grounds: Firstly, the White paper on Welfare had argued for a change in the orientation of social assistance in South Africa, from poverty relief to a more developmental function. The basic income proposal was a step back from this objective. Secondly, there was no support within the ANC and outside for extending grants to the white population, especially given the large income differentials between them and the black population. Thirdly, maintaining fiscal responsibility would have meant reducing the scope and generosity of social assistance in order to finance even a low level of the basic income. (see Figure 1, especially the 'representative democracy' column).

Natrass and Seekings argue that while the ANC came to power committed to redistribution, and was/is expected to bring to effect significant redistribution, its capacity for redistribution has been limited by "... policies that keep the economy growing along an inegalitarian path, with a large section of the poor being shut out of income generating activities" (Nattrass and Seekings, 2001) (p.495). There is debate among researchers on poverty trends in South Africa, but the general view is that poverty rates have remained broadly stagnant since 1994, while demographics has ensured that the numbers in poverty have risen (Leibbrandt et al., 2006; Leibbrandt et al., 2010). Social assistance has been extremely significant in preventing poverty from increasing. Overall, poverty and inequality outcomes remain problematic in South Africa, especially taking account of the fact that expenditure on social assistance has doubled as a proportion of GDP since 1994.

Right of centre politicians and business leaders are increasingly questioning the effectiveness of this large component of public expenditure and commonly voice concerns about potential dependency effects from the grants. Trade Unions have pointed out the fact that unemployed groups constitute a gap in the social assistance grants system. On the left, some NGOs have explored the potential for judicial routes to expanding the grants. ${ }^{48}$ This has tested the position of the government on welfare policy. The equalisation of the age of entitlement to the Old Age Grant to 60 for men and women (it was previously 65 for men), for example, followed a challenge in the courts over possible gender discrimination associated with a differential age of entitlement. NGOs like the Black Sash play an important role in monitoring and facilitating the implementation of social assistance on the ground. They also perform a key role in ensuring welfare rights are fully exercised. (See Figure 1, especially the third and fourth columns)

\footnotetext{
${ }^{46}$ Committee of Inquiry into a Comprehensive System of Social Security for South Africa 2002. Transforming the present. Protecting the future, Draft Consolidated Report Pretoria: Committe of Inquiry into a Comprehensive System of Social Security for South Africa.

${ }^{47}$ See Matisonn, H. and Seekings, J. 2003. The politics of a basicincome grant in South Africa, 1996-2002. In: Standing, G. and Samson, M. (eds.) A basic income grant for South Africa. Cape Town: University of Cape Town. ${ }^{48}$ See Seekings, J. 2008. 'Deserving individuals and groups: The post-apartheid state's justification of the shape of South Africa's system of social assistance'. Transformation, 68: 28-52.
} 
The potential for change and reform of social assistance is limited by the type of politics which sustain the ANC, and the ANC's support for the existing social assistance architecture. Nattrass and Seekings argue persuasively that voter loyalty to the ANC depends on partisan identification with its role in bringing about political change in South Africa. To date, opposition parties are treated with considerable suspicion because of their association with Apartheid; and few breakaway ANC groups have prospered. As Natrass and Seekings put it "Popular discontent over unemployment and job creation was partly offset by relatively more positive assessment with respect to other issues, including fiscal and social policy, even though the electorate regarded unemployment as the most important" (Nattrass and Seekings, 2001) (p.488). Political conditions therefore preclude any large scale reform to social assistance, due to the strength of partisan support for the ANC. At the same time, social assistance is important in maintaining and strengthening this partisan support, particularly in rural areas of the country. The feedback effect of social assistance on politics is therefore significant.

It is important to round up this assessment with a brief discussion of fiscal space. The government of South Africa has benefited from a significant improvement in fiscal revenues over time, from a high base. This has enabled a large expansion of the grants without affecting other areas of government expenditure. There are concerns that further expansion of grants expenditure could place pressure on service provision, especially in the context of the impact of the financial crisis (van der Berg and Siebrits, 2010). Social assistance appears to have hit a ceiling in this respect. On the other hand, the government has committed itself to the introduction of a Comprehensive Social Security System in South Africa, replacing the patchwork of occupational pension plans with a government supported national social insurance scheme. This large-scale social investment will add to fiscal pressures and will have implications on social assistance. It is not surprising that support for a national social insurance scheme comes strongly from trade unions and urban groups.

\subsection{Triangulating the case studies}

Table 1 and 2 provide a summary of key differences and similarities across the case studies. The main diagonal is intentionally left empty. The cells on top of the diagonal summarise similarities/differences in policy making and feedback effects. The cells below the diagonal summarise similarities/differences in implementation and programme dynamics. 


\begin{tabular}{|c|c|c|c|c|}
\hline & & Brazil & India & South Africa \\
\hline & & \multicolumn{3}{|c|}{ Policy making and feedback effects } \\
\hline Brazil & \multirow{3}{*}{ 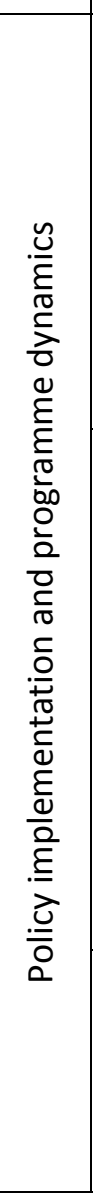 } & NA & $\begin{array}{l}\text { Multiple political parties and fragmented } \\
\text { opposition. } \\
\text { Local/sub-national governments initially } \\
\text { provide social assistance and later national } \\
\text { governments extend them. } \\
\text { Social assistance investment opposed since it } \\
\text { is not a tool for economic growth. } \\
\text { Direct evidence on political parties reelected } \\
\text { to power due to introduction of social } \\
\text { assistance policies. }\end{array}$ & $\begin{array}{l}\text { Debates around new constitution generated new } \\
\text { set of common values and social contract. } \\
\text { Coordination for different social assistance } \\
\text { programmes achieved in progressive manner in } \\
\text { both countries. }\end{array}$ \\
\hline India & & $\begin{array}{l}\text { Constitutional recognition brings } \\
\text { higher parliamentary scrutiny for } \\
\text { Bolsa Familia and NREGA in } \\
\text { Brazil and India respectively and } \\
\text { non-contributory social assistance } \\
\text { programmes do not receive such } \\
\text { scrutiny. } \\
\text { High level of autonomy for lower } \\
\text { levels of administration. }\end{array}$ & NA & $\begin{array}{l}\text { Segmented approach to social assistance (in SA } \\
\text { for whites and in India for employees of organized } \\
\text { sector) exists early on. Later poverty and inclusive } \\
\text { growth becomes key arguments for introduction of } \\
\text { social assistance. } \\
\text { Concentration of poverty in social groups brings } \\
\text { political mileage for policy intervention (identity } \\
\text { politics). } \\
\text { Social assistance instrumental for managing } \\
\text { change: in SA transition from apartheid rule; in } \\
\text { India raising inequality due to liberalization. } \\
\text { Cooptation of academics in the process of } \\
\text { knowledge creation on poverty-linked policies. }\end{array}$ \\
\hline $\begin{array}{l}\text { South } \\
\text { Africa }\end{array}$ & & $\begin{array}{l}\text { Basic income debates form the } \\
\text { basis against which social } \\
\text { assistance programmes are } \\
\text { weighed. }\end{array}$ & $\begin{array}{l}\text { Cross support from different sections of } \\
\text { socially divided voting population generates } \\
\text { facilitative politics for social assistance. } \\
\text { NGOs play significant role in assisting/acting } \\
\text { as countervailing force to government } \\
\text { programmes. }\end{array}$ & 管 \\
\hline
\end{tabular}




\begin{tabular}{|c|c|c|c|c|}
\hline & & Brazil & India & South Africa \\
\hline & & \multicolumn{3}{|c|}{ Policy making and feedback effects } \\
\hline Brazil & \multirow{3}{*}{ 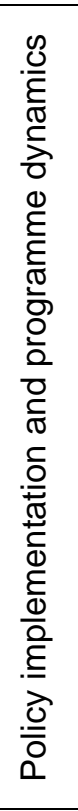 } & NA & $\begin{array}{l}\text { Political party campaigning in Brazil, compared to } \\
\text { India where civil society campaign, which forces } \\
\text { introduction of social assistance. } \\
\text { Decentralisation index brings credibility to politics } \\
\text { as a feedback mechanism in Brazil compared to } \\
\text { demand generation through identity politics in } \\
\text { India. }\end{array}$ & $\begin{array}{l}\text { Municipal initiatives translated as federal level } \\
\text { policy in a consolidation process in Brazil. In } \\
\text { South Africa, social assistance is introduced at } \\
\text { the time of new constitution as a strategy to } \\
\text { support the black population. }\end{array}$ \\
\hline India & & $\begin{array}{l}\text { Autonomous disbursement } \\
\text { agency in Brazil compared with } \\
\text { India's decentralized governance } \\
\text { system (which intensifies } \\
\text { clientelist politics). }\end{array}$ & NA & $\begin{array}{l}\text { High level coordination under single ministry in } \\
\text { South Africa compared to large number of anti- } \\
\text { poverty programmes spread over numerous } \\
\text { ministries in India. }\end{array}$ \\
\hline $\begin{array}{l}\text { South } \\
\text { Africa }\end{array}$ & & $\begin{array}{l}\text { Joint financing by local } \\
\text { government and central } \\
\text { government is present in Brazil. In } \\
\text { South Africa, social assistance is } \\
\text { centrally funded and delivered by } \\
\text { provincial governments. }\end{array}$ & $\begin{array}{l}\text { Limited or no autonomy for local level government } \\
\text { in South Africa compared to high level of discretion } \\
\text { for lower levels of administration and politicians in } \\
\text { India. }\end{array}$ & NA \\
\hline
\end{tabular}


The expansion of social assistance from small privileged groups (whites in South Africa, organized sector employees in India, those able to afford contributory insurance in Brazil) to a broader target population, in line with universal principles, involved intense political process in all case countries. In India an active civil society movement through the 'right to food' campaign formed the medium through with this was articulated. The civil society representatives acting as advisors to a coalition government persuaded the government from within. In Brazil the fragmented opposition parties such as The Workers Party came together to campaign for expansion of municipal initiatives to federal level, resulting in constitutional recognition of social rights for all Brazilians. In South Africa, ANC the party that spearheaded the transition from Apartheid rule immediately facilitated the right to social security to feature in the new constitution. In all these democracies, the parliament plays a critical role in steering the given fiscal capacity for expanding the social rights to all citizens. Since the right to social assistance is constitutionally guaranteed, the judiciary has become a new stakeholder in all the case countries, and from time to time the government is challenged to stand up to the promises. ${ }^{49}$

At the level of programme implementation there are important lessons for each other. Unique features of ranking different municipalities for reaching the target population (holding the politicians accountable) and establishment of an autonomous disbursement agency are powerful tools to create credibility politics in Brazil. In India, decentralized elected bodies are responsible for the delivery of social assistance, while financing is from central government. This has left too much room for manoeuvring policy at the implementation level. Thus, evidence on effectiveness is conflicting. Social audits conducted by NGOs and government agencies have reported conflicting outcomes. The South African system of implementation has a high level of coordination at central ministry level, leaving little discretion and autonomy to local governments. The NGO role in implementation is crucial in India and South Africa, compared to Brazil. In all three countries, the role of multilateral agencies is found to be extremely important especially in providing technical support for implementation.

At the level of programme dynamics the unique features of case countries were more prominent than similarities across cases. This is anticipated since the interaction of programmes with a unique socio-cultural context may produce incomparable dynamics. For instance, corruption that pervades other segments of life and business in India is also remarkably present in all its social assistance programmes. The corruption is politically steered and bureaucratically carried out. Corruption structures access to the programme. On the other hand, in South Africa, the history of Apartheid rule and emergence of ANC leaves limited space for political competition. The economic inequality prevailing between the white and black population has restricted support for of basic income grant proposals within the ANC ranks. In Brazil the political competition between Workers Party and Cardoso's poverty activism has led to the mushrooming of various schemes which are later consolidated into Bolsa Familia replacing erstwhile Bolsa Escola. Despite these differences, there is commonality on debates around the stabilization of social assistance programmes. In all three countries general revenue finances the programme. Thus, debate on providing a stable finance to social assistance is active.

\footnotetext{
${ }^{49}$ In South Africa the judiciary pressed the government to grant equal entitlement ages for old age grant to 60 for men (from 65). The government of India has been challenged in the court to increase the wages of employment guarantee to adjust inflation. In Brazil, the government has been taken to court to identify the threshold of social pension as $1 / 4$ of the minimum wage.
} 
In all three cases, feedback politics is significantly high. Although there had been initial resistance to the grants (compared to development funds) in both South African and India, once the programme is introduced, they gained huge popular support. In Brazil and India the introduction of social assistance has served to overcome anti-incumbency trends in the 2006 and 2009 general elections. In South Africa, the partisan support to ANC has been strengthened because of social assistance. However, depending on the architecture of governance, the feedback effect is different on local level politics. Absence of coordination at central level for different social assistance programmes (and anti-poverty programmes) along with local autonomy has resulted in huge expenditures without convergence attempts in India. This has allowed local elites to turn the resultant divergence into political mileage. At the other extreme, there is a high level of coordination in South Africa by bringing all social assistance programmes under one single ministry. This gives no room for feedback effect on local politics. The Brazilian system allows feedback on local politics as long as politicians can earn credits for reaching the targeted groups.

\section{Discussion: Does politics matter?}

In this section we return to the main questions for the paper as set out in the Introduction, and draw out the main conclusions.

\subsection{Does politics matter for the delivery of effective social assistance?}

The conclusions from the analysis in the paper are that politics has played a central role in the expansion of social assistance in the three countries selected for detailed examination. This is a two-way process. On the one hand political factors are at the core of the adoption, design, and implementation of social assistance. On the other hand, social assistance feeds back into political processes helping reshape them.

What is the influence of politics in shaping social assistance in the South? Our case studies suggest that the influence of politics is strong. At one level, this is an obvious finding. At its core, social assistance is a manifestation of solidarity values in particular countries and communities, values which are themselves political. ${ }^{50}$ Social assistance represents institutions established with the objective of addressing poverty and vulnerability. Their scale and scope reflects shared understandings and the social priority attached to poverty. The main reasons why this finding has purchase on current development discourses arises from the techno-managerial approach often employed by international organisations (Devarajan and Widlund, 2007). This approach often ignores political influences on social protection institutions. The relevance of the politics for social assistance delivery is relatively under researched. Explaining the rapid emergence of social assistance in developing countries has to address this knowledge gap.

To achieve this, a stronger conceptual framework is needed. This framework will need to separate out, as we do in the paper, the different dimensions in which politics matter, and the different dimensions of the influence of politics on social assistance delivery. The examination of three case countries in this study reveals that traditional approaches to this question focused mainly on investigating incentive structures as a motivation for elected politicians and non-elected bureaucrats (Alesina and Tabellini, 2004). This is too limited as a

${ }^{50}$ Rawls' 'political conception of justice' is a comprehensive statement on this point. 
tool for capturing the political dynamics around social assistance in Southern democracies. Social contracts and pacts, key events, ideology, and knowledge are important too. Unlike conventional wisdom, our cases studies suggest several dimensions in which political influences need to be studied. A sole focus on elites, or its polar opposite, the assumption of full political competition is also limited as an approach to social assistance (Krishna, 2006). These different dimensions need to be studied separately and then integrated to form a more comprehensive picture.

Social assistance institutions also help shape political processes. What is the significance and orientation of feedback processes? As noted in the paper, these institutions feedback into political processes at different levels and in different ways. Many studies have discussed, and measured, the role of social assistance in aligning electoral support for incumbents. This dimension, if overemphasised, can reduce social assistance to a purely instrumental function (Hall, 2008). Social assistance should also be considered as a legitimate form of aligning party coalitions and political support around pro-poor policies (Stokes, 2004).

The growing institutionalisation of social assistance as rights through intense political struggle is the story in all three case countries. This redefines groups in poverty as citizens (social citizens). A deepening of democracy follows. In India, for example, informal labourers had little to give and take from the state. Thus, the state's legitimacy itself was limited. Social assistance challenges this relationship and re-establishes legitimacy.

The case studies reveal a complex interaction between local and national politicians and the electorate, as in India and Brazil, but also point to the role of identity politics and filters, as in South Africa. At a higher level of abstraction, social assistance can embody, and therefore strengthen and develop, shared values and preferences. These institutions can firm up and develop social contracts and shared notions of social justice. In many countries, but especially in India, Brazil and South Africa, social assistance is widely perceived as an instrument of inclusion. Just as in low income countries with poorly developed social protection institutions, social assistance can be perceived as an instrument of exclusion. Feedback processes from social assistance and politics have not been studied sufficiently in the literature.

The delivery of social assistance cannot be delinked from local dynamics and politics. Increasingly, political credibility requires procedural fairness. At the implementation stage, efficiency gets redefined as egalitarianism once politics takes centre stage as a means to explain the delivery of social assistance. New Centre-local relations are being created (e.g. joint financing, joint monitoring, joint issue making, joint definition of targets) through the politics of social assistance. Leakages due to poor implementation are part and parcel of political resistance by local elites, in the main resistance to redistribution.

In India there is a stark contrast between the politics of development (roads, drinking water, sanitation) and the politics of social assistance (pension, employment), indicating that politics of social assistance is better conceived as a process than as an arena.

On each component of this two-way process, further research is needed to provide deeper insights. Contrasting the autonomy exercised by Brazilian institutions for delivering social assistance with that of India and South Africa it is important to focus on how effective service 
delivery strengthens political credibility. It is also important to examine in more detail the influence of identity politics, as observed in South Africa and India, in reducing the role of service delivery in affecting credibility based politics (Keefer and Khemani, 2003). Identity politics structures social assistance through stratified mechanisms. Identity politics could also prevent the expansion of social assistance. This is an important area for further research, the linkages existing between (in)effective delivery of social assistance and political credibility.

Decentralisation of power to lower levels of administration could intensify politics around delivery of social assistance. In India the highest impact of feedback processes is through local politics. In Brazil, though decentralisation is significant, the influence of local politics is reduced through strong autonomous institutions at the national level that regulate the delivery of social assistance. In South Africa, high level of coordination of social assistance programmes under a single ministry creates an environment through which local politics gets distanced. In other words, decentralisation has to work with other countervailing forces. If not, as in India, the main outcome is a situation in which authority diffusion is rampant allowing capture of social assistance programmes by local elites.

\subsection{Key approaches, knowledge, and knowledge gaps}

The paper developed a conceptual framework to examine the politics of social assistance in developing countries. This framework identified different dimensions of how politics matters for the expansion of social assistance, and linked these dimensions to the issues of adoption, design, implementation and accountability of social assistance.

The case studies applied this framework in each of the three countries selected. The next step was to develop a comparative analysis of the main findings in the case studies. The framework proved reasonably successful in enabling a comparison across the three countries on each dimension. This helped to identify commonalities and differences across the countries concerned, and also supported more synthetic findings. The framework facilitated a more comprehensive look at the politics of social assistance.

The following knowledge gaps emerged from the analysis:

- Conceptual frameworks developed to study redistribution in welfare states can provide important insights into the expansion of social assistance in developing countries; but they need to be adapted in at least two important respects: (i) redistributive models, especially those relying on welfarist assumptions, are ill suited to the study of non-welfarist poverty reduction; and (ii) neither 'ideal' conditions of political competition nor 'elite capture' models are appropriate to the study of the politics of the expansion of social assistance in developing countries.

- There is a literature providing country-specific or programme specific information and discussion of social assistance. The main knowledge gap, and a key priority, is the need to develop comparative approaches and models.

- The feedback from social assistance to political processes has been studied to some extent in middle income countries for specific countries/programmes. The knowledge gap is at the cross-country comparative level, and at the cross-estate comparative level. Cross-country comparative studies can generate knowledge on the role of political institutions, democratisation, left-right coalitions, and donors, inter alia, in the specific processes and outcomes as regards social assistance delivery. Cross- 
country studies, institutional/qualitative/quantitative, can support useful generalisations on the role of political institutions and processes on the expansion of social assistance. Infra-national comparisons can generate information on the relative influence of national-local politics and bureaucracies.

- There is scarce literature on the extent to which social assistance generates synergies and constraints in the delivery of other services and public goods in developing countries. In the context of human development conditional transfer programmes and employment guarantees, there is a prima facie case for examining these interactions. They have also been observed in pure transfer programmes, like South Africa's and Brazil's social pensions in the context of the bundling of services and transfers.

- There is a need to distinguish, analytically, social contracts and pacts, from scaling up and reform and evolution of social assistance, as was done in the framework above. Different forms of politics apply to these.

- Despite the usual 'development hubris', effective delivery of social assistance and the politics associated can be productively studied in high income countries. Pace the significance of registration (Szreter, 2007); the role of politics in preventing/facilitating social assistance (Lindert, 2004); the role of left parties in social assistance (EspingAndersen, 1990); the shift to 'active' labour market policies following persistent high unemployment in the 1980s (OECD, 2003). It is much less productive to focus on welfare states, which at any rate are a post WWII phenomenon predicated on full employment and 'standard' family structures. It would be useful to take a hardheaded view (no nostalgia) on actual social assistance in high income countries and see what can be learned from this by developing countries. 


\section{References}

Alesina, A. 1999. Too Large and too Small Governments. In: Tanzi, V., Chu, K.-y. and Gupta, S. (eds.) Economic Policy and Equity. Washington DC: International Monetary Fund.

Alesina, A. and Tabellini, G. 2004. Bureaucrats or politicians?, NBER Working Paper 10241. Cambridge MA: NBER.

Ambasta, P., Shankar, P. S. V. and Shah, M. 2008. 'Two years of NREGA: The road ahead'. Economic and Political Weekly, 43: 41-50.

Barrientos, A. 2007. 'Tax-financed social security'. International Social Security Review, 60: 99-117.

Barrientos, A. 2008. Cash transfers for older people reduce poverty and inequality. In: Bebbington, A. J., Dani, A. A., De Haan, A. and Walton, M. (eds.) Institutional Pathways to Equity. Addressing Inequality Traps. Washington DC: The World Bank.

Barrientos, A. 2011. The rise of social assistance in Brazil, Mimeo. Manchester: Brooks World Poverty Institute.

Barrientos, A., Niño-Zarazúa, M. and Maitrot, M. 2010. Social Assistance in Developing Countries Database Version 5, Report. Manchester: Brooks World Poverty Institute.

Besley, T. and Ghatak, M. 2007. 'Reforming public service delivery'. Journal of African Economies, 16: 127-156.

Britto, T. and Soares, F. V. 2010. Bolsa Família e Renda de Cidadania - um passo en falso?, Mimeo. Brasilia: IPEA.

Cecchini, S. and Martínez, R. 2011. Protección social inclusiva en América Latina: Una mirada integral, un enfoque de derechos. Santiago: CEPAL.

Committee of Inquiry into a Comprehensive System of Social Security for South Africa 2002. Transforming the present. Protecting the future, Draft Consolidated Report Pretoria: Committe of Inquiry into a Comprehensive System of Social Security for South Africa.

de Janvry, A., Nakagawa, H. and Sadoulet, E. 2009. Pro-poor targeting and electoral rewards in decentralizing to communities the provision of public goods in rural Zambia, Mimeo. Berkeley: University of California at Berkeley.

de la O, A. L. 2006. Do Poverty Relief Funds Affect Electoral Behaviour? Evidence from a Randomized Experiment in Mexico, Mimeo. Cambridge MA: MIT.

Deacon, B. 1997. Global Social Policy. International organizations and the future of welfare. London: Sage.

Dev, M. 1998. Government interventions and social security for rural labour In: Radhakrishna, R. and Sharma, A. N. (eds.) Empowering Rural Labour in India. New Delhi: Institute for Human Development.

Devarajan, S. and Widlund, I. (eds.) 2007. The politics of service delivery in democracies. Bettter acces for the poor. Stockholm: EGDI Secretariat.

Devereux, S. 2007. 'Social Pensions in Southern Africa in the Twentieth Century'. Journal of Southern African Studies, 33.

Dutta, P., Howes, S. and Murgai, R. 2010. 'Small but effective: India's targeted unconditional cash transfers'. Economic and Political Weekly, 65: 63-70.

Esping-Andersen, G. 1990. The Three Worlds of Welfare Capitalism, Cambridge: Polity Press.

Fiszbein, A. and Schady, N. 2009. Conditional Cash Transfers. Reducing Present and Future Poverty. Washington DC: The World Bank. 
Gelbach, J. B. and Pritchett, L. 1995. Does more for the poor mean less for the poor? The politics of targeting, Policy Research Working Papers 1799. Washington DC: The World Bank.

Giovagnoli, P. 2005. Poverty Alleviation or Political Networking? A combined qual-quant analysis of the implementation of safety nets in post crisis Argentina, 05-66. London: DESTIN, London School of Economics.

Gough, I. and Wood, G. (eds.) 2004. Insecurity and welfare regimes in Asia, Africa and Latin America, Cambridge: Cambridge University Press.

Grosh, M., Del Ninno, C., Tesliuc, E. and Ouerghi, A. 2008. For Protection and Promotion. The Design and Implementation of Effective Safety Nets. Washington DC: The World Bank.

Guhan, S. 1994. 'Social security options for developing countries'. International Labor Review, 133.

Guhan, S. 1995. 'Social expenditures in the union budget'. Economic and Political Weekly, 30.

Hall, A. 2008. 'Brazil's Bolsa Família: A Double-Edged Sword?'. Development and Change, 39: 799-822.

Hanlon, J., Barrientos, A. and Hulme, D. 2010. Just give money to the poor. The Development revolution from the South. Sterling VA: Kumarian Press.

Harriss, J. 2004. How much difference does politics make? Regime differences across Indian states and rural poverty reduction, Destin Working Paper 1. London: LSE DESTIN.

Hickey, S. 2008. Conceptualising the politics of social protection in Africa. In: Barrientos, A. and Hulme, D. (eds.) Social Protection for the Poor and Poorest: Concepts, Policies and Politics. London: Palgrave.

Hickey, S. 2009. 'The politics of Protecting the Poorest: Beyond the Anti-Politics Machine'. Political Geography, 28: 473-483.

Hirway, I. 2003. 'Identification of BPL households for poverty alleviation programmes'. Economic and Political Weekly, 38: 4803-4838.

Jaccoud, L., Hadjab, P. D. E.-M. and Chaibub, J. R. 2009. Assistência social e securança alimentar: Entre novas trajetórias, vehlas agendas e recentes desafíos (1988-2008). In: Diretoría de Etudos e Políticas Sociais (ed.) Políticas sociais: Acompanhamento e análise 17. Brasilia: IPEA.

Jaccoud, L., Hadjab, P. D. E.-M. and Chaibub, J. R. 2010. The consolidation of social assistance in Brazil and its challenges, 1988-2008, Working Paper 76. Brasilia: International Policy Centre.

Jayal, N. G. 2001. Democracy and the state, New Delhi: Oxford University Press.

Keefer, P. and Khemani, S. 2003. The Political Economy of Public Expenditures, Mimeo. Washington DC: The World Bank.

Kohli, A. 1989. The State and Poverty in India, Cambridge: Cambridge University Press.

Krishna, A. 2006. 'Poverty and democratic participation reconsidered: Evidence from the local level in India'. Comparative Politics, 38: 439-458.

Leibbrandt, M., Poswell, L., Naidoo, P. and Welch, M. 2006. Measuring recent changes in South Africa inequality and poverty using 1996 and 2001 census data. In: Bhorat, $\mathrm{H}$. and Kanbur, R. (eds.) Poverty and Policy in Post-Apartheid South Africa. Cape Town: HSRC. 
Leibbrandt, M., Woolard, I., Finn, A. and Argent, J. 2010. Trends in South African Income Distribution and Poverty since the fall of Apartheid, OECD Social, Employment and Migration Working Papers 101. Paris: OECD.

Lindert, K., Linder, A., Hobbs, J. and De la Brière, B. 2007. The nuts and bolts of Brazil's Bolsa Família program: Implementing conditional cash transfers in a decentralized context, Social Protection Discussion Paper 0709. Washington DC: The World Bank.

Lindert, P. H. 2004. Growing Public: Social Spending and Economic Growth Since the Eighteenth Century. Cambridge: Cambridge University Press.

López-Calva, L. F. and Lustig, N. (eds.) 2010. Declining Inequality in Latin America: A decade of progress? Washington DC: Brookings Institution and UNDP.

Lund, F. 1995. 'Changing social policy in South Africa'. Social Policy Review, 7.

Lund, F. 2008. Changing Social Policy. The Child Support Grant in South Africa. Cape Town: HSRC Press.

MacAuslan, I. 2008. India's National Rural Employment Guarantee Act: A case study for how change happens, From Poverty to Power Series. Oxford: OXFAM.

Matisonn, H. and Seekings, J. 2003. The politics of a basicincome grant in South Africa, 1996-2002. In: Standing, G. and Samson, M. (eds.) A basic income grant for South Africa. Cape Town: University of Cape Town.

Meltzer, A. M. and Scott, R. F. 1981. 'A rational theory of the size of government'. Journal of Political Economy, 89: 914-927.

Mesquita, A. C. S., Jaccoud, L. and dos Santos, M. P. G. 2010. Garantia de Renda na Política Social Brasileira: Entre a Proteçao aos Riscos Sociais e o Alivio à Pobreza, Mimeo. Brasilia: IPEA.

Mookherjee, D. 2004. The crisis in government accountability. New Delhi: Oxford University Press.

Nattrass, N. and Seekings, J. 2001. 'Democracy and distribution in highly unequal economies: The case of South Africa'. Journal of Modern African Studies, 39: 471 498.

OECD 2003. 'Benefits and Employment, Friend or Foe? Interactions Between Passive and Active Social Programmes'. Employment Outook 2003: 171-235.

Osmani, S. R. 1991. Social Security in South Asia. In: Ahmad, E., Drèze, J., Hills, J. and Sen, A. (eds.) Social Security in Developing Countries. Oxford: Clarendon Press.

Pellisery, S. 2008. Process deficits in the provision of social protection in rural Maharashtra. In: Barrientos, A. and Hulme, D. (eds.) Social Protection for the Poor and Poorest: Concepts, Policies and Politics. London: Palgrave.

Pellissery, S. 2005. 'Local determinants of exclusion and inclusion in Rural Public Work Programmes: A political economy approach'. International Journal of Rural management, 1: 167-184.

Pellissery, S. and Jalan, S. 2011. "Towards transformative social protection" Gender and Development 19 (2) 284-93

Pellissery, S. and Sanju, S. 2011. NREGA to bridge the missing link for food security: Improving the natural resource access for small land holders. In: Mishra, R. K. and Jayashree, R. (eds.) Millennium Development Goals and India: case assessing performance, prospects and challenges. New Delhi: Allied Publishers.

Plant, R. 2003. 'Citizenship and social security'. Fiscal Studies, 24: 153-166.

Prabhu, S. and Chatterjee, S. 1993. Social sector expenditures and human development: $A$ study of Indian states, Development Research Group Study 6. New Delhi: Reserve Bank of India. 
Raabe, K., Birner, R., Sekher, M., Gayathrivedi, K. G., Shilp, A. and Schiffer, E. 2010. How to overcome governance challenges of implementing NREGA, Discussion Paper 963. Washington DC: IFPRI.

Rawls, J. 1971. A Theory of Justice. Cambridge, MA: Harvard University Press.

Robinson, J. A. 2010. The Political Economy of Redistribution. In: López-Calva, L. F. and Lustig, N. (eds.) Declining inequality in Latin America. A decade of Progress? Washington DC: Brookings Institution Press.

Seekings, J. 2008. 'Deserving individuals and groups: The post-apartheid state's justification of the shape of South Africa's system of social assistance'. Transformation, 68: 2852.

Shankar, S., Gaiha, R. and Jha, R. 2011. 'Information, Access and Targeting: The National Rural Employment Guarantee Scheme in India'. Oxford Development Studies, 39: 69-95.

Stokes, S. C. 2004. Is vote buying undemocratic?, Conference paper. Chicago: University of Chicago, Department of Political Science.

Szreter, S. 2007. 'The right to registration: development, identity registration and social security- A historical perspective'. World Development, 35: 67-86.

van der Berg, S. 1997. 'South African social security under apartheid and beyond'. Development Southern Africa, 14: 481-503.

van der Berg, S. and Siebrits, K. 2010. Social assistance reform during a period of financial stress, Stellenbosch Economic Working Papers 17/10. Stellenbosch: University of Stellenbosch Department of Economics.

Woolard, I. and Leibbrandt, M. 2010. The Evolution and Impact of Unconditional Cash Transfers in South Africa, Working Paper 51, Cape Town: University of Cape Town.

World Bank 2011. Social Protection for Changing India, Report. Washington: The World Bank.

Yadav, Y. and Palshinkar, S. 2009. "Between Fortuna and Virtu: Explaining the Congress' Ambiguous Victory in 2009" Economic and Political Weekly 44 (39).

Zucco, C. 2008. 'The President's 'New' Constituency: Lula and the Pragmatic Vote in Brazil's 2006 Presidential Elections'. Journal of Latin American Studies, 40: 29-49. 


\section{esid}

The Effective States and Inclusive Development Research Centre

The Effective States and Inclusive Development Research Centre (ESID) aims to improve the use of governance research evidence in decision-making. Our key focus is on the role of state effectiveness and elite commitment in achieving inclusive development and social justice.

ESID is a partnership of highly reputed research and policy institutes based in Africa, Asia, Europe and North America. The lead institution is the University of Manchester.

The other founding institutional partners are:

- $\quad$ BRAC Development Institute, BRAC University, Dhaka

- Institute for Economic Growth, Delhi

- Department of Political and Administrative Studies, University of Malawi, Zomba

- $\quad$ Center for Democratic Development, Accra

- $\quad$ Centre for International Development, Harvard University, Boston

In addition to our institutional partners we have established a network of leading research collaborators and policy/uptake experts. 